\title{
Hubungan Kekerabatan Fenetik Pisang di Kecamatan Kabawetan, Kabupaten Kepahiang, Provinsi Bengkulu
}

\author{
Evelyne Riandini ${ }^{1}$, R.R Sri Astuti ${ }^{2}$ \\ 1,2Program Studi Biologi, FMIPA Universitas Bengkulu \\ E-mail: eriandini@unib.ac.id
}

\begin{abstract}
Study of the phenetic relationship between bananas carried out in Kabawetan Subdistrict, Kepahiang District, Bengkulu Province, from April to October 2019. Data collection on banana exploration studies is carried out in 32 several locations of houses and community gardens in the form of one wild plants and six cultivation. Morphological data were compiled based on observations of morphological characters of specimens in the field, the character status was adapted from banana descriptor. Morphological characterization results were observed and continued with character selection based on kinship in the form of a tree phenogram. Data were analyzed using the Numerical Taxonomy System (NTSys-pc) 2.02 program with the Unweighted Pair Group Method dan Arithmetic Mean (UPGMA). The results found 6 types of banana diversity collection from 32 pseudo stands (individuals). The collection results obtained in the field are 1 collection of wild bananas and 5 cultivation collections. There are 6 banana distribution locations, namely Mekasari Village, Sumbersari Village, Babakan Village Bogor, Sumbersari Village, Tugu Rejo Village, Sido Rejo Village. Kinship of 6 types was found to have a similarity coefficient between 0.27 - 0.63. Phenograms divide into 2 large groups of 6 types of bananas, namely group A and group B, these two groups are separated by a similarity coefficient value of 0.27. Group A consists of 5 types of bananas namely kapal, kapok, gembor, and jantan bananas. Group B consists of pisang kluthuk.
\end{abstract}

Keywords: banana, Kabawetan, phenetic, UPGMA-NTSys

\begin{abstract}
Abstrak
Studi kekerabatan fenetik antar pisang dilakukan di Kecamatan Kabawetan, Kabupaten Kepahiang, Provinsi Bengkulu, mulai April hingga Oktober 2019. Pengumpulan data studi eksplorasi pisang di 32 lokasi perkarangan rumah dan kebun masyarakat berupa satu tumbuhan liar dan lima budi daya. Data morfologi disusun berdasarkan pengamatan karakter morfologi di lapangan, status karakter diadaptasi dari deskriptor pisang. Hasil karakterisasi morfologi diamati dan dilanjutkan dengan pemilihan karakter berdasarkan kekerabatan dalam bentuk fenogram pohon. dianalisis menggunakan program Numerical Taxonomy System (NTSys-pc) 2.02 dengan Unweighted Pair Group Method dan Arithmetic Mean (UPGMA). Hasil penelitian ditemukan 6 koleksi jenis keanekaragaman pisang dari 32 tegakan semu (individu). Hasil koleksi yang didapat di lapangan yaitu 1 koleksi pisang liar dan 5 koleksi budi daya. Lokasi persebaran pisang yaitu Desa Mekasari, Desa Sumbersari, Desa Babakan Bogor, Desa Sumbersari, Desa Tugu Rejo, Desa Sido Rejo di Kabawetan Kabupaten Kepahiang Provinsi Bengkulu. Hubungan kekerabatan dari 6 jenis yang ditemukan memiliki nilai koefisien kesamaan anatara 0.27 - 0.63. Fenogram membagi pisang menjadi 2 kelompok besar yaitu kelompok A dan kelompok B yang dipisahkan dengan nilai koefisien kesamaan 0.27. Kelompok A terdiri atas 5 jenis pisang yaitu pisang kapal, pisang raja, pisang kepok, pisang gembor, dan pisang jantan. Kelompok B terdiri atas satu jenis pisang, yaitu pisang kluthuk.
\end{abstract}

Kata kunci: fenetik, Kabawetan, pisang, UPGMA-NTSys

\section{Pendahuluan}

Fenetik (berasal dari kata Yunani, phaino yang berarti terlihat) merupakan klasifikasi berdasarkan pada persamaan taksa secara menyeluruh. Karakter fenetik meliputi karakter morfologi serta karakter anatomi. Karakter fenetik tidak terlalu mengaitkan analisisnya dengan adanya evolusi namun tidak diabaikannya begitu saja (Rustiami, 2007). Karakter fenetik pisang dapat digunakan dalam mengetahui hubungan 
kekerabatan jenis-jenis pisang. Pisang memiliki keragaman morfologi dalam hal bentuk, ukuran, warna buah bervariasi. Cukup banyak variasi dimiliki baik liar dan budidaya.

Pisang dikelompokkan menjadi 2 yaitu pisang tidak memiliki biji yang terdiri atas kurang lebih 500 kultivar dan pisang memiliki biji atau pisang liar yang terdiri atas kurang lebih 70 jenis (Sulistyaningsih, 2013). Sebagian besar pisang liar ditemukan di Asia Tenggara, sehingga daerah Indo-Malaysia merupakan pusat keragaman pisang. Center of diversity pisang tersebar mulai daerah tropis, sub-tropis, Asia, Amerika, Afrika, hingga Australia (De Langhe et al., 2009).

Pisang memberikan kontribusi paling besar terhadap produksi buah-buahan nasional dan menjadi komoditas unggulan di Indonesia (Sulistyaningsih, 2013). Indonesia merupakan pusat keragaman pisang (Musaceae) dan memiliki banyak jenis dan kultivar pisang yang tersebar hampir di seluruh Indonesia. Indonesia memiliki 12 jenis dari 71 jenis pisang yang ada di dunia dan duajenis di antaranya, yaitu Musa acuminata Colla dan Musa balbisiana Colla merupakan nenek moyang pisang budi daya (Poerba et al., 2016). Budidaya buah saat ini tidak hanya dilakukan di pekarangan/ kebun rumah, tetapi telah dilakukan secara intensif terutama pisang untuk keperluan ekspor. Lebih dari 200 kultivar pisang dan 15 jenis pisang liar diketahui hidup di wilayah Indonesia (Nasution \& Yamada 2001).

Kultivar pisang dibudidayakan di beberapa daerah di Sumatera tersebar di Provinsi Sumatera Barat, Bengkulu, Riau, dan Lampung. Pisang yang baru teridentifikasi yaitu pisang rejang dikenal dengan nama pisang kalengkong (Sumatera Barat), pisang serindit, pisang seringgit, pisang kepok (Bengkulu, Lampung) (Sutanto 2014). Hampir seluruh wilayah Indonesia cocok dijadikan kebun pisang (Jumari \& Pudjoarianto 2000) termasuk provinsi Bengkulu. Di provinsi Bengkulu keanekaragaman pisang yang cukup tinggi salah satunya di Kabawetan Kepahiang. Informasi mengenai hubungan kekerabatan fenetik pisang di Kabupaten Rejang Lebong masih terbatas. Sehubungan dengan perihal tersebut, maka dilakukan penelitian hubungan kekerabatan fenetik pisang (Musaceae) di Kabawetan Kepahiang, Provinsi Bengkulu.

\section{Metode Penelitian}

Penelitian dilaksanakan bulan JuliOktober 2019 dengan studi eksplorasi di 32 lokasi perkarangan rumah dan kebun masyarakat berupa 1 tumbuhan liar dan 5 budi daya. Lokasi berupa pekarangan rumah dan kebun masyarakat di Kabawetan Kepahiang. Identifikasi koleksi tumbuhan dan analisis dilakukan di Laboratorium Biosistematika Tumbuhan, Basic Science FMIPA, UNIB.

Perlengkapan teknis maupun non teknis penelitian ini adalah kamera digital, kertas label, kertas koran, tali ukur, luxmeter, meteran, plastik ukuran besar, plastik klip, silika gel, alkohol, peta, GPS, kompas, soil tester, bingkai pengepres (kardus/aluminium bergelombang), etiket gantung, buku identifikasi dan jurnal untuk determinasi, laptop, dan perlengkapan tulis.

Pengambilan spesimen dan data koleksi menggunakan studi jelajah (eksplorasi) yaitu pengambilan data dengan cara menelusuri atau menjelajahi lokasi tempat penelitian berupa lokasi budidaya pisang maupun tumbuhan liar yang tumbuh di pekarangan rumah dan kebun masyarakat di Kabawetan. Spesimen diambil dari tanaman yang berbunga dan berbuah. Pembuatan herbarium mengikuti metode Rugayah et al. (2004). Masing-masing individu dikoleksi dan dibuat spesimennya sebanyak 3 hingga 5 duplikat dan spesimen herbarium akan disimpan di Laboratorium Sistematika Tumbuhan Biologi Universitas Bengkulu.

Spesimen tanaman pisang dikoleksi yaitu pisang yang memiliki ciri morfologi lengkap, memiliki bagian vegetatif (batang semu, daun, dan anakan) dan bagian reproduktif (bunga, buah, biji jika ada) (Jumari dan Pudjoarinto 2000). Identifikasi morfologi menggunakan panduan deskriptor pisang dari International Plant Genetic Resources Institute (IPGRI 1996). Identifikasi meliputi karakter 
batang semu, tangkai daun, daun, bunga, dan buah.

Data morfologi disusun berdasarkan 59 karakter morfologi hasil spesimen di lapangan, status karakter yang diadaptasi dari deskriptor pisang (IPGRI 1996). Hasil karakter berupa data kualitatif (bentuk, tipe, dan warna) dan kuantitatif (panjang, lebar, dan jumlah). Hasil karakaterisasi morfologi yang diamati selanjutnya dilakukan pemilihan karakter berdasarkan pohon kekerabatan (dendrogram), kelompok karakter mempertimbangkan syarat-syarat karakter distinct, uniform, dan stable dengan memperhatikan kesederhanaan demi kepraktisan tanaman budidaya.

Data pengamatan morfologi disajikan dalam bentuk skor, selanjutnya digunakan untuk membuat matriks kemiripan genetik dengan menggunakan prosedur SIMQUAL
(Similarity for Qualitatif Data). Matriks kemiripan ini digunakan untuk analisis pengelompokan Sequential, Angglomerative, Hierarcichal and Nested (SAHN), clustering dengan metode Unweighted Pair Group Method dan Arithmetic Mean (UPGMA) menggunakan program komputer NTSys-pc versi 2.02 (Rohlf 1998).

\section{Hasil Penelitian dan Pembahasan}

Hasil penilitian jenis-jenis pisang liar dan budi daya di Kabawetan Kabupaten Kepahiang Provinsi Bengkulu didapatkan 6 koleksi pisang. Hasil koleksi yang didapat di lapangan yaitu 1 koleksi pisang liar dan 5 koleksi budi daya. Dari 6 koleksi pisang liar dan budidaya, hasil inventarisasi di lapangan didapatkan 32 tegakan semu (individu) (Tabel 1).

Tabel 1. Hasil koleksi pisang di Kecamatan Kabawetan, Kabupaten Kepahiang, Provinsi Bengkulu

\begin{tabular}{|c|c|c|c|c|c|c|}
\hline No & Koleksi & Karakteristik & Nama ilmiah & $\begin{array}{c}\text { Nama } \\
\text { lokal }\end{array}$ & $\begin{array}{l}\text { Status biologi } \\
\text { (Liar dan } \\
\text { Budidaya) }\end{array}$ & $\begin{array}{l}\text { Jumlah } \\
\text { tegakan semu } \\
\text { (individu) }\end{array}$ \\
\hline 1 & Koleksi 1 & $\begin{array}{l}\text { Karakteristik } \\
\text { tinggi tegakan } \\
\text { pelepah kurang } \\
\text { dari } 2 \mathrm{~m} \text {, warna } \\
\text { tegakan pelepah } \\
\text { hijau }\end{array}$ & $\begin{array}{l}\text { Pisang Kapal (PK) } \\
\text { (Musa acuminata } \\
\text { Colla) Klasfikasi } \\
\text { taksonomi : } \\
\text { Musa-Eumusa-AAA }\end{array}$ & $\begin{array}{l}\text { Pisang } \\
\text { besak }\end{array}$ & Budidaya & 2 \\
\hline 2 & Koleksi 2 & $\begin{array}{l}\text { Karakteristik } \\
\text { tinggi tegakan } \\
\text { pelepah } \pm 2 \\
\text { sampai } 3 \mathrm{~m}, \\
\text { Daun pisang } \\
\text { tumbuh } \\
\text { merunduk }\end{array}$ & $\begin{array}{l}\text { Pisang Gembor (PG) } \\
\text { (Musa acuminata x } \\
\text { Musa balbisiana) } \\
\text { Klasifikasi } \\
\text { taksonomi : Musa- } \\
\text { Eumusa-AAB }\end{array}$ & $\begin{array}{l}\text { Pisang } \\
\text { gembor }\end{array}$ & Budidaya & 1 \\
\hline 3 & Koleksi 3 & $\begin{array}{l}\text { Karakteristik } \\
\text { tinggi tegakan } \\
\text { pelepah lebih } \\
\text { dari } 3 \mathrm{~m} \text {, warna } \\
\text { tegakan pelepah } \\
\text { hijau } \\
\text { kekuningan, dan } \\
\text { bagian dalam } \\
\text { tegakan pelepah } \\
\text { hijau terang. }\end{array}$ & $\begin{array}{l}\text { Pisang Jantan (PJ) } \\
\text { (Musa acuminata } \\
\text { Colla) Klasifikasi } \\
\text { taksonomi: } \\
\text { Musa-Eumusa-AA }\end{array}$ & $\begin{array}{l}\text { Pisang } \\
\text { Jantan }\end{array}$ & Liar & 6 \\
\hline
\end{tabular}


Al-Hayat: Journal of Biology and Applied Biology, Vol 3, No 2 (2020), 111-117

DOI. 10.21580/ah.v3i2.5910

Copyright (c) 2020 Al-Hayat: Journal of Biology and Applied Biology

\begin{tabular}{|c|c|c|c|c|c|c|}
\hline No & Koleksi & Karakteristik & Nama ilmiah & $\begin{array}{l}\text { Nama } \\
\text { lokal }\end{array}$ & $\begin{array}{c}\text { Status biologi } \\
\text { (Liar dan } \\
\text { Budidaya) }\end{array}$ & $\begin{array}{l}\text { Jumlah } \\
\text { tegakan semu } \\
\text { (individu) }\end{array}$ \\
\hline 4 & Koleksi 4 & $\begin{array}{l}\text { Pisang monyet } \\
\text { tinggi tegakan } \\
\text { pelepah } \pm 2 \\
\text { sampai } 3 \mathrm{~m} \text {, } \\
\text { warna tegakan } \\
\text { pelepah coklat } \\
\text { keunguan, dan } \\
\text { bagian dalam } \\
\text { tegakan pelepah } \\
\text { putih. Bentuk } \\
\text { free tepal bulat } \\
\text { telur, } \\
\text { perkembangan } \\
\text { ujung free tepal } \\
\text { sangat } \\
\text { berkembang }\end{array}$ & $\begin{array}{l}\text { Pisang Klutuk PHD- } \\
101 \\
\text { (Musa balbisiana } \\
\text { Colla) Klasifikasi } \\
\text { taksonomi: } \\
\text { Musa-Eumusa-BB }\end{array}$ & $\begin{array}{l}\text { Pisang } \\
\text { Moyet }\end{array}$ & $\begin{array}{l}\text { Budidaya } \\
\text { (berbiji) }\end{array}$ & 5 \\
\hline 5 & Koleksi 5 & $\begin{array}{l}\text { Karakteristik } \\
\text { tegakan tinggi } \\
\text { pohon } \geq 3 \mathrm{~m} \text {. } \\
\text { Warna batang } \\
\text { hijau } \\
\text { kemerahan. } \\
\text { Bentuk kanal } \\
\text { daun ke-3 } \\
\text { margin } \\
\text { melengkung ke } \\
\text { dalam. Buah } \\
\text { yang berbentuk } \\
\text { petak }\end{array}$ & $\begin{array}{l}\text { Pisang Kepok } \\
\text { (Musa acuminata x } \\
\text { Musa balbisiana) } \\
\text { Klasifikasi } \\
\text { taksonomi: } \\
\text { Musa-Eumusa-ABB }\end{array}$ & $\begin{array}{l}\text { Pisang } \\
\text { Kepok }\end{array}$ & Budidaya & 10 \\
\hline 6 & Koleksi 6 & $\begin{array}{l}\text { Karakteristik } \\
\text { berkas bunga } \\
\text { jantan dan } \\
\text { braktea tua } \\
\text { tidak meluruh, } \\
\text { masih } \\
\text { menempel pada } \\
\text { rakis.. tegakan } \\
\text { tinggi } \geq 3 \mathrm{~m} . \\
\text { Jenis daun } \\
\text { terkulai } \\
\text { (drooping). } \\
\text { Warna batang } \\
\text { hijau } \\
\text { kemerahan. }\end{array}$ & $\begin{array}{l}\text { Pisang Raja } \\
\text { (Musa acuminata x } \\
\text { Musa balbisiana) } \\
\text { Klasifikasi taksonmi: } \\
\text { Musa-Eumusa-AAB }\end{array}$ & $\begin{array}{l}\text { Pisang } \\
\text { Rajo }\end{array}$ & Budidaya & 8 \\
\hline
\end{tabular}

Hasil analisis data untuk menggunakan hasil pengamatan data mengetahui hubungan kekerabatan morfologi spesimen didapatkan (fenetik) pisang liar dan budidaya di fenogram kekerabatan (Gambar 1). Kabawetan Kepahiang, disusun 


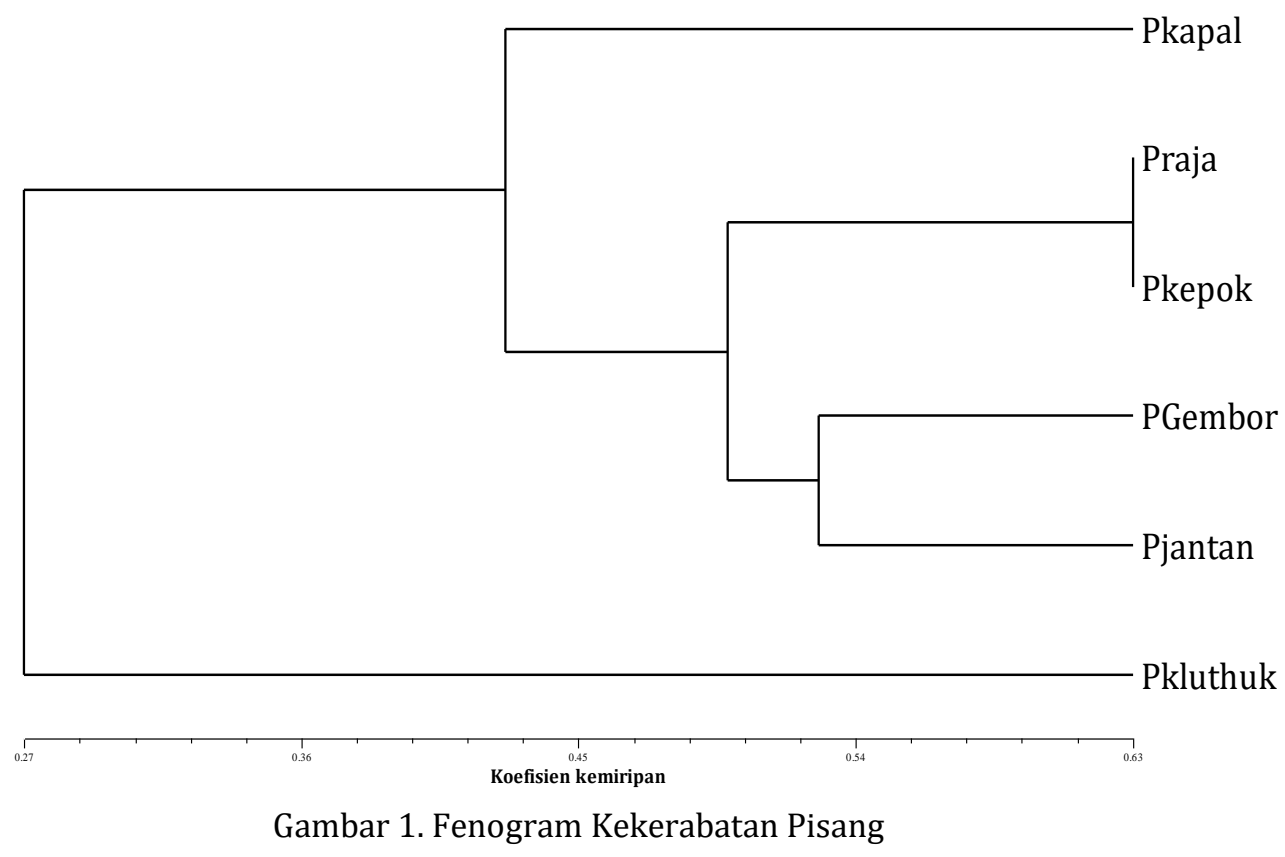

Hasil fenogram ini dianalisis menggunakan data pengamatan morfologi yaitu 59 karakter, disajikan dalam bentuk skor, selanjutnya digunakan untuk membuat matriks kesamaan genetik dengan menggunakan prosedur SIMQUAL (Similarity for Qualitatif Data). Matriks kemiripan ini digunakan untuk analisis pengelompokan Sequential, Angglomerative, Hierarcichal and Nested (SAHN), pengelompokan dengan metode Unweighted Pair Group Method dan Arithmetic Mean (UPGMA) menggunakan program komputer NTSys-pc versi 2.02 (Rohlf 1998).

Hasil kekerabatan fenetik pisang dari 6 koleksi ditemukan memiliki nilai koefisien kesamaan anatara $0.27-0.63$. Hasil analisis fenogram membagi 6 koleksi pisang menjadi 2 kelompok besar berupa kelompok A dan kelompok B. Kelompok besar ini dipisahkan dengan nilai koefisien kesamaan 0.27. Kelompok A terdiri dari 5 jenis pisang yaitu pisang kapal, pisang raja, pisang kepok, pisang gembor, dan pisang jantan.

Kelima koleksi pisang ini termasuk kedalam 2 jenis Musa acuminata Colla yaitu pisang kapal, dan pisang jantan. 3 jenis Musa acuminata $x$ Musa balbisiana yaitu pisang kepok, pisang gembor, dan pisang raja. Secara taksonomi 2 jenis Musa acuminata Colla yaitu pisang kapal merupakan kelompok MusaEumusa-genom AAA, sedangkan pisang kapal kelompok Musa-Eumusa-genom AA. 3 jenis Musa acuminata $x$ Musa balbisiana yaitu pisang kepok merupakan kelompok MusaEumusa-genom ABB, pisang gembor kelompok Musa-Eumusa-genom AAB, pisang raja kelompok Musa-Eumusa-genom BB

Secara fenogram kelompok A teridri dari pisang kapal, pisang raja, pisang kepok, pisang gembor, dan pisang jantan. Pisang kapal langsung terpisah cabang fenogramnya dengan nilai koefisien kesamaan 0.51 . Hal ini sesuai dengan klasifikasi taksonomi genom koleksi pisang yang diteliti. Pisang kapal memiliki karakter petiole berwarna merah keunguan, bilah kedua sisinya runcing, dan perilaku bract jatuh menggulung. Ini adalah salah satu karakteristik dari Musa-Eumusagenom AA, sedangkan pisang kapal memiliki karakteristik pembeda yaitu karakter bentuk bilah kedua sisi membulat dan perilaku bract sebelum jatuh tidak menggulung (Poerba et al 2016). 


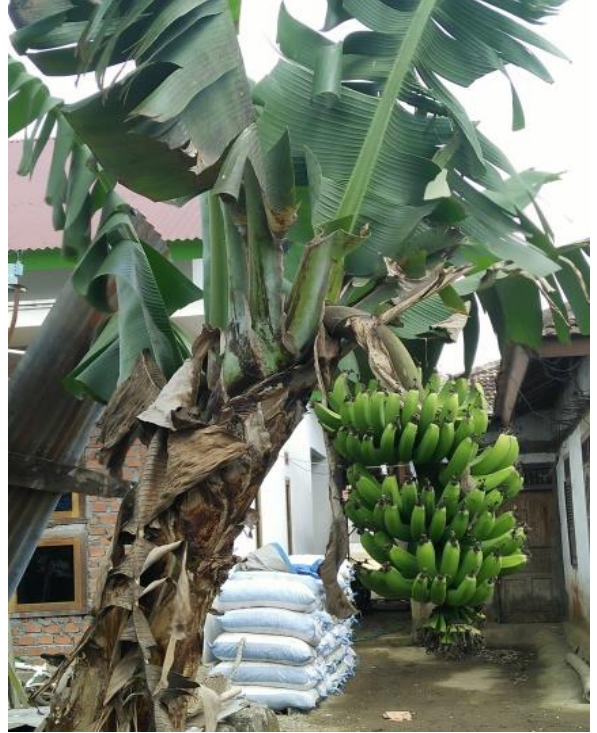

Gambar 1. Pisang Kapal

Sumber: Dokumentasi Pribadi

Pisang raja dan pisang kepok memiliki nilai koefisien kemiripan 0.63 dengan krakteristik warna batang hijau kemerahan warna permukaan midrib ventral hijau. perilaku bract tidak menggulung. Karakteristik ini yang membuat kedua jenis tersebut mirip, secara nama ilmiah 2 jenis ini termasuk ke kelompok Musa acuminata $x$ Musa balbisiana. Secara taksonomi dibedakan berdasarkan genom yiatu pisang kepok MusaEumusa- genom ABB sedangkan pisang raja Musa-Eumusa-genom AAB.
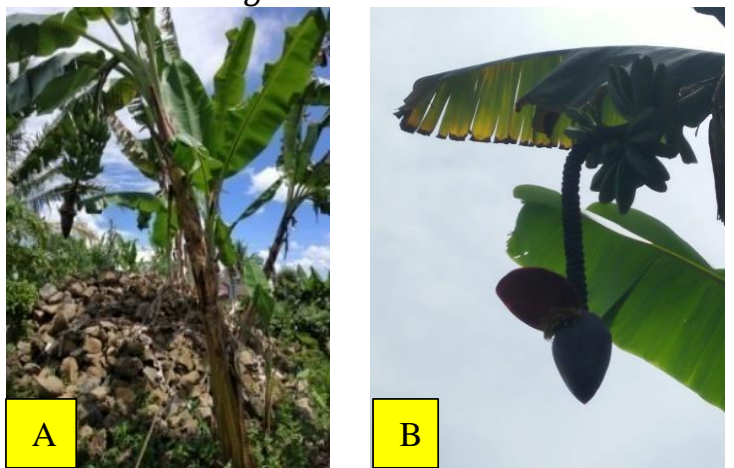

Gambar 1. A. Pisang Raja dan B. Pisang Kepok Sumber: Dokumentasi Pribadi

Pisang gembor dan pisang jantan memiliki nilai koefisien kemiripan 0.52 dengan karakteristik pembeda yaitu bentuk basis daun warna permukaan ventral rakis dan bentuk jantung pisang. Secara taksonomi pisang gembor masuk ke dalam jenis Musa acuminata $x$ Musa balbisiana dengan kelompok Musa-Eumusa-genom AAB, sedangkan pisang jantan jenis Musa acuminata Colla masuk ke dalam kelompok Musa-Eumusa-genom AA. Kelompok ini memliki pembagian kelompok yang kurang tepat, ini disebabkan karena dalam pengambilan data karakter morfologi tidak sesuai dengan deskriptor pisang dari International Plant Genetic Resources Institute (IPGRI 1996).
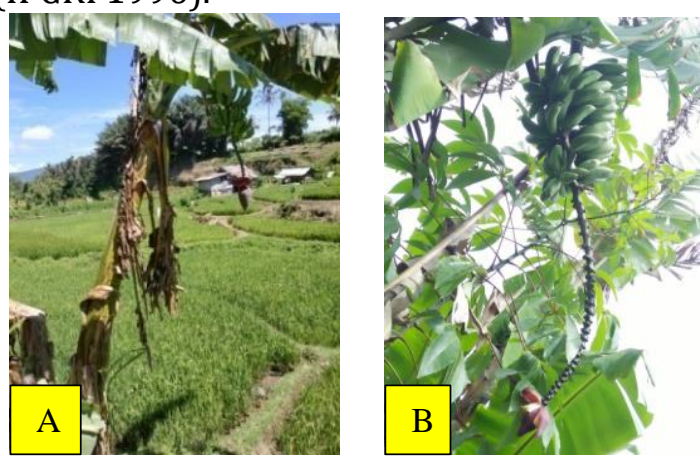

Gambar 2 A. Pisang Gembor dan B. Pisang Jantan Sumber: Dokumentasi Pribadi

Kelompok B dipisahkan nilai koefisien kemiripan 0.27 dengan jumlah 1 jenis pisang yaitu pisang klutuk PHD-101 (Pisang monyet) (PM) yaitu Musa balbisiana Colla, kelompok Musa-Eumusa-BB. Karakteristik yang membedakan, warna tegakan pelepah coklat keunguan, dan bagian dalam tegakan pelepah putih, warna permukaan dorsal rakis daun kuning, warna permukaan ventral rakis daun hijau, dan daun simetris. Bentuk jantung pisang monyet membundar, bentuk free tepal bulat telur, pisang monyet memiliki bentuk buah lurus dibagian distal, dan sisa tangkai putik pada ujung buah tanpa peninggalan tangkai putik Hapsari (2014).
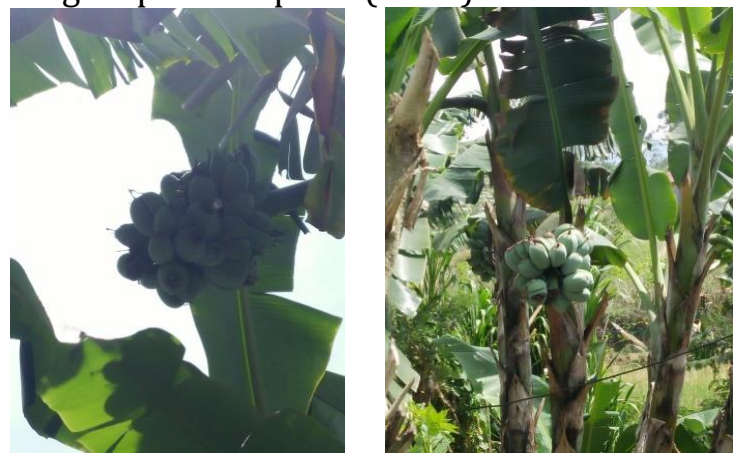

Gambar 3. Pisang klutuk Sumber: Dokumentasi Pribadi 


\section{Simpulan dan Saran}

Simpulan

Hasil penelitian keanekaragaman pisang liar dan budi daya di Kabawetan Kabupaten Kepahiang Provinsi Bengkulu ditemukan 6 koleksi jenis keanekaragaman pisang dari 32 tegakan semu (individu). Hasil koleksi didapat di lapangan yaitu 1 koleksi pisang liar dan 5 koleksi budi daya oleh masyarakat di Kabawetan Kabupaten Kepahiang Provinsi Bengkulu

Hubungan kekerabatan pisang liar dan budi daya di Kabawetan Kabupaten Kepahiang Provinsi Bengkulu, dari 6 jenis yang ditemukan memiliki nilai koefisien kesamaan antara 0.27 - 0.63. Fenogram membagi 6 jenis pisang menjadi 2 kelompok besar yaitu kelompok A dan kelompok B, dua kelompok ini dipisahkan dengan nilai koefisien kesamaan 0.27. Kelompok A memiliki jumlah 5 jenis pisang yaitu pisang kapal, pisang raja, pisang kepok, pisang gembor, dan pisang jantan. Kelompok B terdiri atas satu jenis pisang, yaitu pisang kluthuk.

\section{Ucapan Terima Kasih}

Ucapan terima kasih untuk PNBP Biologi Tahun 2019 Fakultas MIPA Universitas Bengkulu yang telah membiayai penelitian ini, serta kepada dua orang mahasiswa kami Nur Fitria dan M. Reicky telah membantu dalam pelaksanaan penelitian ini.

\section{Daftar Pustaka}

De Langhe, E. et al. (2009) 'Why Bananas Matter: An Introduction to The History of Banana Domestication', Ethnobotany Research and Applications, 7, pp. 165-178.

Hapsari, L. (2014) 'Wild Musa Species Collection of Purwodadi Botanic Garden: Inventory and Its Morphotaxonomic Review', the Journal of
Tropical Life Science, 4(1), pp. 70-80. doi: 10.11594/jtls.04.01.12.

International Plant Genetic Resources Institute (IPGRI) 1996, Descriptor for Banana (Musa spp.), Montpellier, IPGRIINIBAB/CIRAD.

Jumari \& Pudjoarianto A. 2000. Kekerabatan Fenetik Kultivar Pisang Di Jawa.. J. Biologi 2(9):531-542.

Nasution, R. E. and Yamada, I. (2001) PisangPisang Liar di Indonesia. Bogor: Puslitbang Biologi-LIPI.

Poerba, Y. S. et al. (2016) Katalog Pisang Koleksi Kebun Plasma Nutfah Pisang Pusat Penelitian Biologi. Jakarta: Lembaga Ilmu Pengetahuan Indonesia (LIPI).

Rohlf FJ. 1998. NTSYSpc, Numerical Taxonomy and Multivariate Analysis System Version 2.0. User Guide. New York, U.S: Applied Biostatic Inc.

Rustiami, H. (2007) „Klasifikasi Fenetik Versus Filogenetik Sejajarkah ?", Rampak Serantau, 46, pp. 214-222.

Rugayah, Retnowati A, Windadri FI, Hidayat A. 2004. Pengumpulan Data Taksonomi. Di dalam: Rugayah, Widjaja EA, Praptiwi, editor. Pedoman Pengumpulan Data Keanekaragaman Flora. Bogor (ID): Pusat Penelitian Biologi-Lembaga Ilmu Pengetahuan Indonesia.

Sutanto A, D Sukma, C Hermanto and S Sudarsono. 2014. Isolation and characterization of resistance gene analogue (RGA) from Fusarium resistant banana cultivars. Emirates Journal of Food and Agriculture 26(6), 508-518.

Simmonds NW \& Sheperd K. 1955. The taxonomy and origins of the cultivated bananas. J. Linn. Soc. Lond. Bot. 55: 302-312.

Sulistyaningsih, L. D. (2013) Pisang-Pisangan (Musaceae) di Gunung Watuwila dan Daerah Sekitarnya', Floribunda, 4(5), pp. 121-125. 